\title{
Actibacter sediminis gen. nov., sp. nov., a marine bacterium of the family Flavobacteriaceae isolated from tidal flat sediment
}

Correspondence

Chang-Jun Cha cjcha@cau.ac.kr

\author{
Ju-Hyoung Kim, ${ }^{1}$ Ki-Youn Kim, ${ }^{1}$ Young-Tae Hahm, ${ }^{1}$ Bong-Soo Kim, ${ }^{2}$ \\ Jongsik Chun ${ }^{2}$ and Chang-Jun Cha ${ }^{1}$
}

\author{
${ }^{1}$ Department of Biotechnology and BET Institute, Chung-Ang University, Anseong 456-756, \\ Republic of Korea \\ ${ }^{2}$ School of Biological Sciences and Institute of Microbiology, Seoul National University, \\ Seoul 151-742, Republic of Korea
}

\begin{abstract}
A yellow-pigmented, Gram-negative, aerobic bacterial strain comprising rod-shaped cells devoid of flagellar and gliding motility, designated strain $\mathrm{JC}_{2} 129^{\top}$, was isolated from tidal flat sediment of Dongmak on Ganghwa Island, South Korea. Results from a 16S rRNA gene sequence analysis indicated that the isolate belonged to the family Flavobacteriaceae; the highest level of nucleotide sequence similarity $(91.9 \%)$ occurred with Polaribacter dokdonensis DSW $-5^{\top}$. The predominant cellular fatty acids were iso- $\mathrm{C}_{15: 0}(19.8 \%)$, iso- $\mathrm{C}_{15: 1} \mathrm{G}(14.0 \%)$, iso- $\mathrm{C}_{17: 0} 3-\mathrm{OH}$ $(13.7 \%)$ and iso- $\mathrm{C}_{13: 0}(6.4 \%)$. Flexirubin-type pigments were absent. The major isoprenoid quinone was MK-6. The DNA G +C content was 43-45 mol\%. Data from a polyphasic taxonomy study suggested that the isolate represents a novel genus and species in the family

Flavobacteriaceae, for which the name Actibacter sediminis gen. nov., sp. nov. is proposed. The type strain of Actibacter sediminis is $\mathrm{JC} 129^{\top}\left(=\mathrm{KCTC} 12704^{\top}=\mathrm{JCM} 14002^{\top}\right)$.
\end{abstract}

Tidal flats in Korea have been known to harbour a highly diverse prokaryotic community, as shown by both culturedependent and culture-independent surveys (Kim et al., 2004, 2005; Yi \& Chun, 2006). In this study, we report the description of a novel member of this bacterial community, a Flavobacterium-like bacterium that showed low levels of $16 \mathrm{~S}$ rRNA gene sequence similarity with respect to members of the family Flavobacteriaceae with validly published names.

A bacterial strain, designated JC2129 $9^{\mathrm{T}}$, was isolated from a sample of tidal flat sediment from Ganghwa Island, South Korea $\left(37^{\circ} 36^{\prime} 22.3^{\prime \prime} \mathrm{N} 126^{\circ} 22^{\prime} 59.4^{\prime \prime} \mathrm{E}\right)$, using the standard dilution plating method on marine agar 2216 (MA; Conda). The isolate was routinely cultured on MA and maintained at $-80{ }^{\circ} \mathrm{C}$ as a suspension in marine broth (MB; Conda) supplemented with $20 \%$ (v/v) glycerol.

The 16S rRNA gene was amplified enzymically from a single colony by means of a PCR using AccuPower PCR Premix (Bioneer) and primers 27F and 1492R (Lane, 1991). The PCR product was purified using an AccuPrep PCR purification kit (Bioneer) and the sequencing of the

The GenBank/EMBL/DDBJ accession number for the 16S rRNA gene sequence of the strain JC2129 ${ }^{\top}$ is EF670651.

A transmission electron micrograph of a negatively stained cell of strain $\mathrm{JC} 2129^{\top}$ is shown as a supplementary figure available with the online version of this paper.
16S rRNA gene was performed with an Applied Biosystems ABI3730XL automatic sequencer at Macrogen Corp. (Seoul, South Korea). The identification of phylogenetic neighbours and the calculation of pairwise 16S rRNA gene sequence similarities were achieved using the EzTaxon server (http://www.eztaxon.org/; Chun et al., 2007). The initial similarity analyses indicated that our isolate belonged to the family Flavobacteriaceae. The almostcomplete 16S rRNA gene sequence of strain $\mathrm{JC}_{2} 129^{\mathrm{T}}$ (1374 bp) was aligned manually against those of representatives of the family Flavobacteriaceae using the bacterial $16 S$ rRNA secondary structure model and the jPHYDIT program (Jeon et al., 2005). The phylogenetic tree was inferred by using the neighbour-joining method (Saitou \& Nei, 1987) on the basis of distance matrix data. Evolutionary distance matrices for the neighbour-joining method were generated according to the model of Jukes \& Cantor (1969). The resultant neighbour-joining tree topology was evaluated by means of bootstrap analyses (Felsenstein, 1985) based on 1000 resamplings. Phylogenetic analyses were carried out using the MEGA3 (Kumar et al., 2004) and PHYLIP (Felsenstein, 2005) programs.

On the basis of the 16S rRNA gene sequence analyses, strain JC2 $129^{\mathrm{T}}$ showed low levels of similarity with respect to known species of the family Flavobacteriaceae. The highest level of sequence similarity was found with respect 
to Polaribacter dokdonensis DSW $-5^{\mathrm{T}}(91.9 \%)$, followed by Tenacibaculum litoreum CL-TF13 ${ }^{\mathrm{T}}$ (91.9\%) and Lutibacter litoralis CL-TF09 ${ }^{\mathrm{T}}$ (91.6\%). Phylogenetic treeing (Fig. 1) also confirmed that the tidal flat isolate $\mathrm{JC} 2129^{\mathrm{T}}$ is a member of the family Flavobacteriaceae but distantly associated with the aforementioned genera. The tree suggested that strain $\mathrm{JC} 2129^{\mathrm{T}}$ formed a monophyletic clade with the genera Lutibacter, Polaribacter and Tenacibaculum, with $99 \%$ bootstrap support.

The cellular morphology was examined using transmission electron microscopy, after growth of strain JC2 $129^{\mathrm{T}}$ on MA at $30{ }^{\circ} \mathrm{C}$ for 2 days. Gliding motility was investigated by examining the edge of a hanging drop of a fresh $\mathrm{MB}$ culture, as recommended by Bernardet et al. (2002). Anaerobic growth was evaluated on MA in an anaerobicchamber system (Coy Laboratory Products). The $\mathrm{pH}$ range (3-10, using increments of $1 \mathrm{pH}$ unit) for growth was determined using $\mathrm{MB}$; the final $\mathrm{pH}$ was adjusted with $\mathrm{NaOH}$ and $\mathrm{HCl}$ solutions after autoclaving. The requirements for $\mathrm{NaCl}(0-10 \%$, using increments of $1 \%$, w/v) and sea salts $(0,1,3,5,7,10,15$ and $20 \%$, w/v; Sigma) were tested in R2A medium (Conda). The temperature range for growth was determined on MA at $5-50{ }^{\circ} \mathrm{C}$ (using increments of $5{ }^{\circ} \mathrm{C}$ ). Hydrolysis of casein, starch and Tween 80 was tested using MA, as described by Smibert \& Krieg (1994). Chitin hydrolysis was tested on chitin agar as described by Hsu \& Lockwood (1975). Cellulase activity was tested by observing the disintegration of filter paper in an MB culture (Smibert \& Krieg, 1994; Bernardet et al., 2002). DNase test agar (Difco) supplemented with $2.5 \%$ $(\mathrm{w} / \mathrm{v}) \mathrm{NaCl}$ was used for a DNase assay. $\mathrm{H}_{2} \mathrm{~S}$ production was detected in triple-sugar-iron agar supplemented with $2.5 \%(\mathrm{w} / \mathrm{v}) \mathrm{NaCl}$. Arginine dihydrolase, $\beta$-galactosidase, nitrate reduction, urease, acid production from glucose and indole-production tests were performed using an API 20NE kit (bioMérieux) according to the manufacturer's instructions; other enzymic activities were determined using an API ZYM kit (bioMérieux). Kits were inoculated with a heavy bacterial suspension in half-strength artificial seawater $\left(24 \mathrm{~g} \mathrm{NaCl}, 5.1 \mathrm{~g} \mathrm{MgCl}_{2}, 4 \mathrm{~g} \mathrm{Na}_{2} \mathrm{SO}_{4}, 1.1 \mathrm{~g} \mathrm{CaCl}_{2}\right.$, $0.7 \mathrm{~g} \mathrm{KCl}, 0.2 \mathrm{~g} \mathrm{NaHCO}_{3}, 0.1 \mathrm{~g} \mathrm{KBr}, 0.027 \mathrm{~g} \mathrm{H}_{3} \mathrm{BO}_{3}$, $0.024 \mathrm{~g} \mathrm{SrCl}_{2}$ and $0.003 \mathrm{~g} \mathrm{NaF}$ per litre distilled water; Lyman \& Fleming, 1940) and AUX media (bioMérieux) supplemented with $2.5 \%(\mathrm{w} / \mathrm{v}) \mathrm{NaCl}$. Carbon-source utilization was tested by incubating strain $\mathrm{JC} 2129^{\mathrm{T}}$ at $37{ }^{\circ} \mathrm{C}$ for 2 weeks on basal agar medium supplemented with yeast extract $(0.64 \mathrm{~g} \mathrm{KCl}, 23.6 \mathrm{~g} \mathrm{NaCl}, 5.94 \mathrm{~g}$ $\mathrm{MgSO}_{4} \cdot 7 \mathrm{H}_{2} \mathrm{O}, 4.53 \mathrm{~g} \mathrm{MgCl}_{2} \cdot 6 \mathrm{H}_{2} \mathrm{O}, 1.3 \mathrm{~g} \mathrm{CaCl} 2.2 \mathrm{H}_{2} \mathrm{O}$, $0.2 \mathrm{~g} \mathrm{NH}_{4} \mathrm{Cl}, 0.2 \mathrm{~g} \mathrm{NaNO}_{3}, 15 \mathrm{~g}$ Bacto agar and $0.05 \mathrm{~g}$ yeast extract per litre distilled water; Choi \& Cho, 2006) containing $0.2 \%$ carbon source.

A transmission electron micrograph of strain $\mathrm{JC} 129^{\mathrm{T}}$ is available as Supplementary Fig. S1 in IJSEM Online. Its biochemical and physiological properties are presented in Table 1 and in the genus and species descriptions.

Chemotaxonomic characteristics were determined from cells grown at $30{ }^{\circ} \mathrm{C}$ for $2-3$ days on $\mathrm{MA}$ or in $\mathrm{MB}$. Analysis of the fatty acid methyl esters was carried out by GLC according to the instructions of the Microbial Identification system (MIDI). Isoprenoid quinones were isolated by using the method of Minnikin et al. (1984) and were analysed by HPLC (Varian) as described by Collins (1985). The DNA G + C content was determined by HPLC analysis of deoxyribonucleosides as described by Mesbah et al. (1989), using a reversed-phase column (Supelcosil LC18 S; Supelco). Experiments were performed in triplicate.

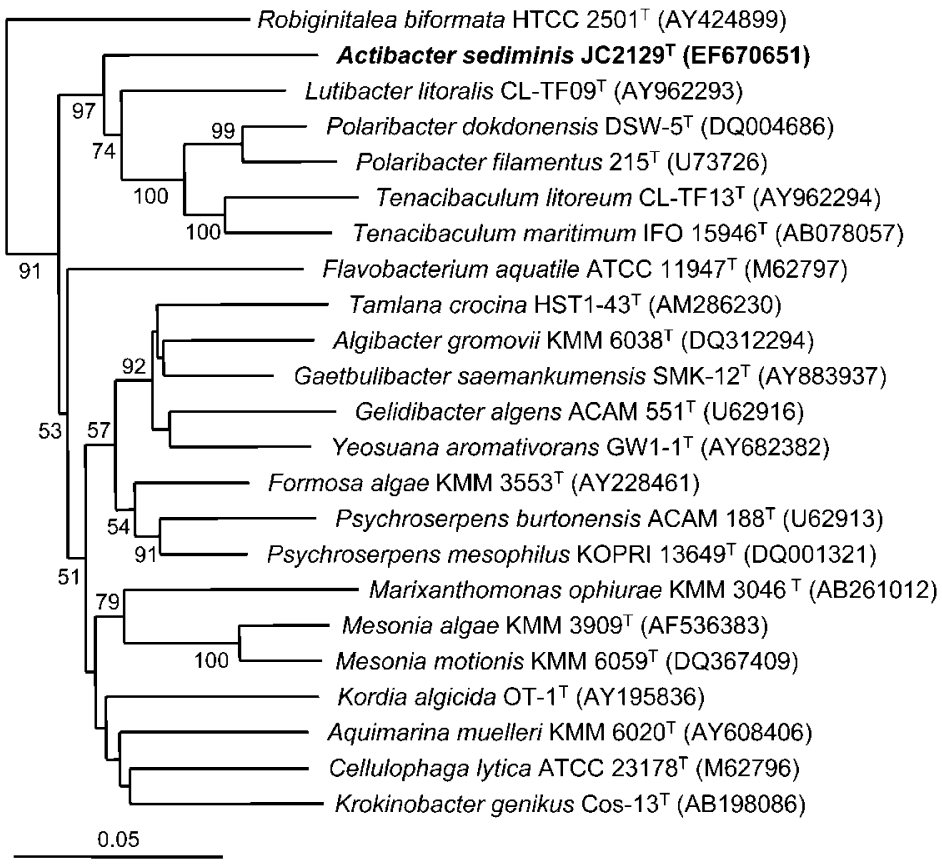

Fig. 1. Neighbour-joining phylogenetic tree, based on almost-complete 16S rRNA gene sequences, showing the relationships between strain $\mathrm{JC} 2129^{\top}$ and representative members of the family Flavobacteriaceae. Bootstrap percentages greater than $50 \%$ (based on neighbour-joining analyses of 1000 resampled datasets) are shown at nodes. Flexibacter flexilis ATCC $23079^{\top}$ (M62794) (not shown) was used as an outgroup. Bar, 0.05 nucleotide substitutions per position. 
Flexirubin-type pigments were sought by using the $\mathrm{KOH}$ test as described by Bernardet et al. (2002).

The cellular fatty acid profiles of strain $\mathrm{JC} 2129^{\mathrm{T}}$ and related members of the family Flavobacteriaceae are shown in Table 2. The major respiratory quinone was MK-6, but a rather large amount of MK-7 was also found (MK-7/MK-6 ratio, $1: 2.8)$. Flexirubin-type pigments were not detected. The DNA G + C content of strain JC2129 ${ }^{\mathrm{T}}$ was found to be 43-45 mol\%.

Strain JC2129 ${ }^{\mathrm{T}}$ exhibited low levels of $16 \mathrm{~S}$ rRNA gene sequence similarity $(<92 \%)$ with respect to all recognized species of the family Flavobacteriaceae, and formed a distinct phyletic line. In addition, several phenotypic properties readily served to differentiate the isolate from its phylogenetic neighbours (Table 1). On the basis of the data from this polyphasic study, strain JC2129 ${ }^{\mathrm{T}}$ represents a novel genus and species of the family Flavobacteriaceae, for which the name Actibacter sediminis gen. nov., sp. nov. is proposed.
Description of Actibacter gen. nov.

Actibacter (Ac.ti.bac'ter. L. n. acta seaside; N.L. masc. n. bacter rod; N.L. masc. n. Actibacter rod from the seaside).

Cells are rod-shaped with rounded ends, non-flagellated and non-gliding. Gram-negative. Aerobic, chemoheterotrophic and mesophilic. Oxidase- and catalase-positive. Spores are not formed. Flexirubin-type pigments are absent. The major isoprenoid quinone is MK-6. The predominant cellular fatty acids are iso- $\mathrm{C}_{15: 0}$, iso- $\mathrm{C}_{15: 1} \mathrm{G}$, iso- $\mathrm{C}_{17: 0} 3-\mathrm{OH}$ and iso- $\mathrm{C}_{13: 0}$. As determined by $16 \mathrm{~S}$ rRNA gene sequence analysis, the genus Actibacter is a member of the family Flavobacteriaceae. The type species is Actibacter sediminis.

\section{Description of Actibacter sediminis sp. nov.}

Actibacter sediminis (se.di.mi'nis. L. gen. n. sediminis of a sediment).

Table 1. Differential characteristics of strain $\mathrm{JC} 2129^{\top}$ and related organisms in the family Flavobacteriaceae

Taxa: 1, strain JC2129 ${ }^{\mathrm{T}}$; 2, Polaribacter (data for six species); 3, Tenacibaculum (nine species); 4, Lutibacter litoralis. Data are from Gosink et al. (1998), Suzuki et al. (2001), Frette et al. (2004), Yoon et al. (2005), Choi et al. (2006), Choi \& Cho (2006) and this study. +, Positive; -, negative; $\mathrm{V}$, variable among species; NA, not available.

\begin{tabular}{|c|c|c|c|c|}
\hline Characteristic & 1 & 2 & 3 & 4 \\
\hline Isolation source(s) & Tidal flat & $\begin{array}{l}\text { Seawater or } \\
\text { saprophytic }\end{array}$ & $\begin{array}{l}\text { Seawater, tidal flat, } \\
\text { saprophytic or parasitic }\end{array}$ & Tidal flat \\
\hline Production of flexirubin-type pigments & - & $\mathrm{v}$ & $\mathrm{v}$ & - \\
\hline Sea-salt requirement & - & $\mathrm{V}$ & $\mathrm{v}$ & + \\
\hline $25{ }^{\circ} \mathrm{C}$ & + & - & + & + \\
\hline $37^{\circ} \mathrm{C}$ & + & - & $\mathrm{V}$ & - \\
\hline \multicolumn{5}{|l|}{ Hydrolysis of: } \\
\hline Starch & + & + & $\mathrm{v}$ & + \\
\hline Gelatin & + & $\mathrm{V}$ & $+\dagger$ & + \\
\hline Aesculin & + & $\mathrm{v}$ & - & + \\
\hline Citrate & + & - & $\mathrm{v}$ & + \\
\hline Glycerol & - & $\mathrm{v}$ & $-\S$ & - \\
\hline L-Leucine & - & - & $\mathrm{v}$ & + \\
\hline Pyruvate & + & - & $-\S$ & + \\
\hline Succinate & - & - & $-\S$ & + \\
\hline Sucrose & + & $\mathrm{v}$ & $\mathrm{V}$ & - \\
\hline L-Proline & - & - & $\mathrm{v}$ & - \\
\hline L-Glutamate & + & $\mathrm{V}$ & $\mathrm{v}$ & - \\
\hline DNA G $+C$ content $(\mathrm{mol} \%)$ & $43-45$ & $31-33$ & $29-33$ & 33.9 \\
\hline
\end{tabular}

*All species except Tenacibaculum skagerrakense are positive for this characteristic.

$\dagger$ Data not available for T. skagerrakense.

\#All species except Polaribacter glomeratus are negative for this characteristic.

§Data not available for Tenacibaculum lutimaris. 
Table 2. Cellular fatty acid compositions of strain JC2129 and type strains of related organisms in the family Flavobacteriaceae

Strains: 1 , JC2129 $; 2$, Polaribacter filamentus $215^{\mathrm{T}}$ (data from Gosink et al., 1998); 3, Tenacibaculum maritimum JCM $8137^{\mathrm{T}}$ (Yoon et al., 2005); 4, L. litoralis JCM $13034^{\mathrm{T}}$ (Choi \& Cho, 2006). Strain JC2129 ${ }^{\mathrm{T}}$, T. maritimum JCM $8137^{\mathrm{T}}$ and L. litoralis JCM $13034^{\mathrm{T}}$ were grown on MA at $30{ }^{\circ} \mathrm{C}$ for $1-2$ days, whereas $P$. filamentus $215^{\mathrm{T}}$ was grown on seawater-cytophaga medium at $5{ }^{\circ} \mathrm{C}$ for $3-4$ weeks. Values are percentages of total fatty acids; components amounting to less than $1 \%$ of the total fatty acids in all strains are not included. -, Not detected/not reported.

\begin{tabular}{|lrccc|}
\hline Fatty acid & $\mathbf{1}$ & $\mathbf{2}$ & $\mathbf{3}$ & $\mathbf{4}$ \\
\hline iso-C $_{13: 0}$ & 6.4 & 5 & 1.8 & - \\
iso-C $_{15: 0}$ & 19.8 & 22 & 16.8 & 16.7 \\
iso-C $_{15: 1} \mathrm{G}$ & 14.0 & 12 & - & 4.2 \\
iso-C $_{16: 0}$ & 1.2 & - & 0.3 & - \\
anteiso-C $_{15: 1} \mathrm{~A}$ & 1.2 & - & - & 1.6 \\
anteiso-C $_{15: 0}$ & 3.7 & 6 & 0.8 & 15.1 \\
$\mathrm{C}_{15: 1} \omega 6 c$ & 5.2 & 9 & 2.2 & 1.5 \\
$\mathrm{C}_{17: 1} \omega 6 c$ & 2.3 & - & 0.3 & 1.0 \\
$\mathrm{C}_{17: 1} \omega 8 c$ & 1.7 & - & - & - \\
$\mathrm{C}_{15: 0} 2-\mathrm{OH}$ & 2.2 & - & 1.1 & 2.1 \\
$\mathrm{C}_{15: 0} 3-\mathrm{OH}$ & 2.1 & 2 & 3.8 & 1.5 \\
$\mathrm{C}_{17: 0} 2-\mathrm{OH}$ & 1.6 & - & - & - \\
$\mathrm{C}_{17: 0} 3-\mathrm{OH}$ & 2.9 & - & 0.6 & - \\
iso-C & 1.2 & - & 5.0 & 13.4 \\
iso- $_{17: 0} 3-\mathrm{OH}$ & 13.7 & - & 13.7 & 3.9 \\
iso- $_{17: 1} \omega 9 c$ & 3.7 & - & - & - \\
Summed $_{2}$ & 4.8 & - & 17.9 & 1.0 \\
\hline
\end{tabular}

${ }^{\star}$ Summed features represent groups of fatty acids that cannot be separated by GLC with the MIDI system. Summed feature 3 comprised iso- $\mathrm{C}_{15: 0} 2-\mathrm{OH}$ and/or $\mathrm{C}_{16: 1} \omega 7 c$.

Cells are $0.7-0.9 \mu \mathrm{m}$ wide and $2.4-3.2 \mu \mathrm{m}$ long. Colonies on MA are circular, smooth, convex, entire and yellowpigmented. Growth occurs at $5-45{ }^{\circ} \mathrm{C}$ (optimum, $37{ }^{\circ} \mathrm{C}$ ), at pH 5-8 (optimum, $\mathrm{pH} 6$ ) and in the presence of $1-10 \%$ $\mathrm{NaCl}$ (optimum, $1-3 \%$ ) or $1-15 \%$ sea salts (optimum, $1 \%)$. Growth also occurs on R2A medium in the absence of $\mathrm{NaCl}$ and sea salt. Nitrate is not reduced to nitrite. Indole and $\mathrm{H}_{2} \mathrm{~S}$ are not produced. Aesculin, gelatin, starch and Tween 80 are degraded, but DNA, agar, casein, crystalline cellulose (filter paper) and chitin are not. Alkaline phosphatase, esterase (C4), esterase lipase (C8), $\alpha$-chymotrypsin, acid phosphatase, naphthol-AS-BI-phosphohydrolase and $\alpha$-glucosidase activities are present, but lipase (C14), leucine arylamidase, valine arylamidase, cystine arylamidase, trypsin, $\alpha$-galactosidase, $\beta$-galactosidase, $\beta$-glucosidase, $\beta$-glucuronidase, $N$-acetyl- $\beta$-glucosaminidase, $\alpha$-fucosidase and $\alpha$-mannosidase activities are absent. Acid is not produced from glucose, arabinose, mannose, mannitol, $\mathrm{N}$-acetylglucosamine, maltose, gluconate, caprate, adipate, malate, citrate or phenylacetate. Growth occurs on peptone, tryptone and yeast extract.
Acetate, citrate, pyruvate, sucrose and L-glutamate are utilized. Glycerol, L-leucine, L-proline, succinate, benzoate, L-proline and $p$-toluic acid are not utilized. The predominant cellular fatty acids are iso- $\mathrm{C}_{15: 0}(19.8 \%)$, iso- $\mathrm{C}_{15: 1} \mathrm{G}$ $(14.0 \%)$, iso- $\mathrm{C}_{17: 0} 3-\mathrm{OH}(13.7 \%)$ and iso- $\mathrm{C}_{13: 0}(6.4 \%)$. The DNA G $+\mathrm{C}$ content is $43-45 \mathrm{~mol} \%$.

The type strain, JC2129 $\left(=\right.$ KCTC $\left.12704^{\mathrm{T}}=\mathrm{JCM} 14002^{\mathrm{T}}\right)$, was isolated from sediment of getbol (a Korean word for tidal flat) on Ganghwa Island, South Korea.

\section{Acknowledgements}

We thank Dr J. P. Euzéby for help with the nomenclature. This work was supported by a Korea Research Foundation grant (KRF-331C00248) funded by the Korean Government (MOEHRD).

\section{References}

Bernardet, J. F., Nakagawa, Y. \& Holmes, B. (2002). Proposed minimal standards for describing new taxa of the family Flavobacteriaceae and emended description of the family. Int J Syst Evol Microbiol 52, 1049-1070.

Choi, D. H. \& Cho, B. C. (2006). Lutibacter litoralis gen. nov., sp. nov., a marine bacterium of the family Flavobacteriaceae isolated from tidal flat sediment. Int J Syst Evol Microbiol 56, 771-776.

Choi, D. H., Kim, Y. G., Hwang, C. Y., Yi, H., Chun, J. \& Cho, B. C. (2006). Tenacibaculum litoreum sp. nov., isolated from tidal flat sediment. Int J Syst Evol Microbiol 56, 635-640.

Chun, J., Lee, J.-H., Jung, Y., Kim, M., Kim, S., Kim, B. K. \& Lim, Y. W. (2007). EzTaxon: a web-based tool for the identification of prokaryotes based on $16 \mathrm{~S}$ ribosomal RNA gene sequences. Int J Syst Evol Microbiol 57, 2259-2261.

Collins, M. D. (1985). Analysis of isoprenoid quinones. Methods Microbiol 18, 329-366.

Felsenstein, J. (1985). Confidence limits on phylogenies: an approach using the bootstrap. Evolution 39, 783-791.

Felsenstein, J. (2005). PHYLIP (phylogeny inference package), version 3.6. Distributed by the author. Department of Genome Sciences, University of Washington, Seattle, USA.

Frette, L., Jørgensen, N. O. G., Irming, H. \& Kroer, N. (2004). Tenacibaculum skagerrakense sp. nov., a marine bacterium isolated from the pelagic zone in Skagerrak, Denmark. Int J Syst Evol Microbiol 54, 519-524.

Gosink, J. J., Woese, C. R. \& Staley, J. T. (1998). Polaribacter gen. nov., with three new species, $P$. irgensii sp. nov., $P$. franzmannii sp. nov. and $P$. filamentus sp. nov., gas vacuolate polar marine bacteria of the Cytophaga-Flavobacterium-Bacteroides group and reclassification of 'Flectobacillus glomeratus' as Polaribacter glomeratus comb. nov. Int J Syst Bacteriol 48, 223-235.

Hsu, S. C. \& Lockwood, J. L. (1975). Powdered chitin agar as a selective medium for enumeration of actinomycetes in water and soil. Appl Microbiol 29, 422-426.

Jeon, Y.-S., Chung, H., Park, S., Hur, I., Lee, J.-H. \& Chun, J. (2005). jPHYDIT: a JAVA-based integrated environment for molecular phylogeny of ribosomal RNA sequences. Bioinformatics 21, 3171-3173.

Jukes, T. H. \& Cantor, C. R. (1969). Evolution of protein molecules. In Mammalian Protein Metabolism, vol. 3, pp. 21-132. Edited by H. N. Munro. New York: Academic Press. 
Kim, B. S., Oh, H. M., Kang, H., Park, S. S. \& Chun, J. (2004). Remarkable bacterial diversity in the tidal flat sediment as revealed by 16S rDNA analysis. J Microbiol Biotechnol 14, 205-211.

Kim, B. S., Oh, H. M., Kang, H. \& Chun, J. (2005). Archaeal diversity in tidal flat sediment as revealed by $16 \mathrm{~S}$ rDNA analysis. J Microbiol 43, 144-151.

Kumar, S., Tamura, K. \& Nei, M. (2004). MEGA3: integrated software for molecular evolutionary genetics analysis and sequence alignment. Brief Bioinform 5, 150-163.

Lane, D. J. (1991). 16S/23S rRNA sequencing. In Nucleic Acid Techniques in Bacterial Systematics, pp. 115-175. Edited by E. Stackebrandt \& M. Goodfellow. Chichester: Wiley.

Lyman, J. \& Fleming, R. H. (1940). Composition of sea water. J Mar Res 3, 134-146.

Mesbah, M., Premachandran, U. \& Whitman, W. B. (1989). Precise measurement of the $\mathrm{G}+\mathrm{C}$ content of deoxyribonucleic acid by highperformance liquid chromatography. Int J Syst Bacteriol 39, 159-167.

Minnikin, D. E., O’Donnell, A. G., Goodfellow, M., Alderson, G. Athalye, M., Schaal, A. \& Parlett, J. H. (1984). An integrated procedure for the extraction of bacterial isoprenoid quinones and polar lipids. J Microbiol Methods 2, 233-241.
Saitou, N. \& Nei, M. (1987). The neighbor-joining method: a new method for reconstructing phylogenetic trees. Mol Biol Evol 4, 406-425.

Smibert, R. M. \& Krieg, N. R. (1994). Phenotypic characterization. In Methods for General and Molecular Bacteriology, pp. 607-654. Washington, DC: American Society for Microbiology.

Suzuki, M., Nakagawa, Y., Harayama, S. \& Yamamoto, S. (2001). Phylogenetic analysis and taxonomic study of marine Cytophaga-like bacteria: proposal for Tenacibaculum gen. nov. with Tenacibaculum maritimum comb. nov. and Tenacibaculum ovolyticum comb. nov., and description of Tenacibaculum mesophilum sp. nov. and Tenacibaculum amylolyticum sp. nov. Int J Syst Evol Microbiol 51, 1639-1652.

Weeks, O. B. (1981). Preliminary studies of the pigments of Flavobacterium breve NCTC 11099 and Flavobacterium odoratum NCTC 11036. In The Flavobacterium-Cytophaga Group, pp. 108-114. Edited by O. B. Weeks. Weinheim: Gesellschaft für Biotechnologische Forschung.

Yi, H. \& Chun, J. (2006). Thalassobius aestuarii sp. nov., isolated from tidal flat sediment. J Microbiol 44, 171-176.

Yoon, J.-H., Kang, S.-J. \& Oh, T.-K. (2005). Tenacibaculum lutimaris sp. nov., isolated from a tidal flat in the Yellow Sea, Korea. Int J Syst Evol Microbiol 55, 793-798. 